\title{
Effects of Partial Replacement of Rice in a Rice Diet by Tapioca Flour on the Metabolism of Nitrogen, Calcium and Phosphorus in Adult Human Beings
}

\author{
By H. B. N. MURTHY, M. SWAMINATHAN AND V. SUBRAHMANYAN \\ Central Food Technological Research Institute, Mysore, India
}

(Received 8 June I953)

In a previous paper from this laboratory, Subrahmanyan, Murthy \& Swaminathan ( 1954 ) reported that replacement of $25 \%$ of the rice in a poor rice diet by tapioca flour did not affect the overall nutritive value of the diet as judged by the growth of young rats. Though animal experiments may provide useful information on the nutritive value of human diets, the ultimate test must be their effect on human beings. It was, therefore, felt desirable to conduct experiments on adult human beings to find out the effect on the metabolism of nitrogen, calcium and phosphorus of replacement of $25 \%$ of rice in poor rice diets by tapioca flour. The results are reported in this paper.

\section{METHODS}

Subjects. Six healthy adult males who carried out ordinary duties in the laboratory were chosen as experimental subjects. They were first clinically examined and found free from any disease. They had not suffered from any debilitating disease in the recent past and had been maintaining a constant weight over a few months before they came under experiment. They were housed in a building specially designed for human metabolic studies on the Institute premises and were kept under strict supervision during the experimental period. Data regarding the age, height and weight of the subjects are given in Table $\mathbf{r}$.

Plan of the experiment. The subjects were fed on a rice diet (Table 2) during the first experimental period and on a rice-tapioca diet (Table 2) during the second experimental period. Each experimental period was of 12 days' duration. The first 7 days of each experimental period constituted a preliminary period to allow the subjects to get accustomed to the diet; hence the collection of urine and faeces was confined to the last 5 days of each experimental period.

Experimental diets and feeding of subjects. The composition of the diets consumed by the subjects is shown in Table 2. The rice diet was similar in composition to that consumed in normal times by a vast majority of the people in south India. The subjects ate four times a day, at breakfast, lunch, tea and dinner. Breakfast and tea consisted of a savoury dish made of rice flour, or a mixture of rice and tapioca flour, and a cup of coffee. Lunch and dinner consisted of cooked rice, unleavened cakes made of rice flour or a mixture of rice and tapioca flours, vegetable soup (a preparation containing pulses, tamarind, chillies, spices, salt and vegetables) and watered buttermilk. Careful records of the food consumed daily by the subjects were made through- 
I2 H. B. N. Murthy, M. Swaminathan and V. Subrahmanyan 1954 out the experiment. It was found during the preliminary periods that the quantities of food consumed by the different subjects were nearly equal. So equal quantities of the different foods were offered to the subjects during the collection period.

\begin{tabular}{|c|c|c|c|}
\hline $\begin{array}{c}\text { Subject } \\
\text { no. }\end{array}$ & $\begin{array}{c}\text { Age } \\
\text { (years) }\end{array}$ & $\begin{array}{c}\text { Height } \\
\text { (cm) }\end{array}$ & $\begin{array}{l}\text { Weight } \\
\text { (kg) }\end{array}$ \\
\hline I & 26 & 162.5 & 45.5 \\
\hline 2 & 37 & $165^{\circ} \circ$ & 50.9 \\
\hline 3 & 35 & $171^{1} 5$ & 50.9 \\
\hline 4 & 29 & 1610 & 50.0 \\
\hline 5 & 31 & $165^{\circ}$ & $48 \cdot 2$ \\
\hline 6 & 22 & 164.0 & $50 \cdot 0$ \\
\hline
\end{tabular}

Table 2. Average daily food consumption of subjects on the rice and the rice-tapioca diet

\begin{tabular}{|c|c|c|}
\hline Constituent & $\begin{array}{l}\text { Rice diet } \\
\text { (g) }\end{array}$ & $\begin{array}{l}\text { Rice-tapioca diet } \\
(\mathrm{g})\end{array}$ \\
\hline Rice & $683 \cdot 3$ & $533 \cdot 3$ \\
\hline Tapioca flour & - & 183.3 \\
\hline Red gram dhal (Cajanus indicus) & 50 & 50 \\
\hline Groundnut oil & 50 & 50 \\
\hline Potatoes & $4 \mathbf{r}$ & $4 \mathrm{r}$ \\
\hline Brinjal (Solanum melongena) & $4 \mathrm{I}$ & $4 \mathrm{I}$ \\
\hline Amaranth (Amaranthus gangeticus) & $2 \mathbf{I}$ & $2 \mathbf{I}$ \\
\hline Whole-milk powder (Nespray) & 9 & 9 \\
\hline $\begin{array}{l}\text { Cane sugar } \\
\text { Tamarind }\end{array}$ & $\begin{array}{l}35 \\
16\end{array}$ & $\begin{array}{l}35 \\
16\end{array}$ \\
\hline Common salt (crude)* & 35 & 35 \\
\hline Bengal gram dhal (Cicer arietinum) & 3.3 & 3.3 \\
\hline Black gram dhal (Phaseolus mungo) & 33 & $3 \cdot 3$ \\
\hline Curry leaves (Murraya koenigii) & I.5 & 1.5 \\
\hline Coriander leaves & $I \cdot 5$ & $1 \cdot 5$ \\
\hline Onions & 8 & 8 \\
\hline Chillies (green) & 7.5 & $7 \cdot 5$ \\
\hline Lemon juice & $3 \mathrm{ml}$. & $3 \mathrm{ml}$. \\
\hline
\end{tabular}

Specimens of the cooked dishes (excluding rice), equivalent to the average quantities consumed daily by each subject, were collected daily and dried in an air oven, powdered and analysed for nitrogen, calcium and phosphorus. Rice was analysed separately.

Collection and preservation of urine and faeces. Urine was collected in bottles containing $100 \mathrm{ml}$. conc. $\mathrm{HCl}$ (A.R.) and $5 \mathrm{~g}$ phenol (A.R.) as preservatives. The urine samples were made up to volume daily and a portion of the daily collection was stored in a refrigerator for analysis. The faeces were mixed with $100 \mathrm{ml}$ of $5 \%$ oxalic-acid solution and $100 \mathrm{ml}$. of an alcoholic solution containing $5 \mathrm{~g}$ each of thymol and phenol and were dried in an air oven at $70-80^{\circ}$. The dried faeces were weighed, powdered and analysed for nitrogen, calcium and phosphorus.

Analytical methods. The nitrogen content of food, urine and faeces was estimated by the micro-Kjeldahl method, calcium by McCrudden's (IgII-I2) method, and phosphorus by the method of Fiske \& Subbarow (1925). For the determination of 
calcium and phosphorus in the urine, a portion of the urine to be analysed was first neutralized to $\mathrm{pH} 7$ by the addition of sodium-hydroxide solution (A.R.), $2 \mathrm{~g}$ sodium acetate (A.R.) were then added and the mixture was evaporated to dryness in a porcelain dish over a water-bath. The residue was incinerated and the calcium and phosphorus present in the ash were determined by the methods referred to above.

RESULTS

The results obtained for nitrogen metabolism are given in Table 3, for calcium metabolism in Table 4, and for phosphorus metabolism in Table 5.

The salt used for the preparation of the diets shown in Tables 2-5 was the usual bazaar variety which is consumed over a large part of India. Our recent investigations have shown that this salt usually contains about $93-96 \%$ sodium chloride together

Table 3. Average daily intake, excretion and balance of nitrogen of subjects on rice and rice-tapioca diets

$\begin{array}{lcccccc} & \begin{array}{c}\text { Calorie } \\ \text { intake } \\ \text { (Cal.) }\end{array} & \begin{array}{c}\text { Nitrogen } \\ \text { intake } \\ (\mathrm{g})\end{array} & \begin{array}{c}\text { Urinary } \\ \text { nitrogen } \\ \text { Diet }\end{array} & \begin{array}{c}\text { Faecal } \\ \text { nitrogen } \\ (\mathrm{g})\end{array} & \begin{array}{c}\text { Total } \\ \text { nitrogen } \\ \text { excreted } \\ (\mathrm{g})\end{array} & \begin{array}{c}\text { Nitrogen } \\ \text { balance } \\ (\mathrm{g})\end{array} \\ \text { Rice } & \mathbf{3 2 1 5} & 9 \cdot 69 & 4.18 & 2.87 & 7.05 & 2.65 \\ \text { Rice-tapioca } & 3337 & 8.93 & 3.50 & 2.68 & 6.18 & 2.75 \\ \text { Difference } & - & -0.76 & -0.68 \pm 0.27 & -0.19 \pm 0.22 & -0.87 & 0.10 \pm 0.30\end{array}$

Table 4. Average daily intake, excretion and balance of calcium of subjects on rice and rice-tapioca diets

\begin{tabular}{|c|c|c|c|c|c|c|}
\hline Diet & $\begin{array}{c}\text { Calorie } \\
\text { intake } \\
\text { (Cal.) }\end{array}$ & $\begin{array}{c}\text { Calcium } \\
\text { intake } \\
\text { (mg) }\end{array}$ & $\begin{array}{l}\text { Urinary } \\
\text { calcium } \\
\text { (mg) }\end{array}$ & $\begin{array}{l}\text { Faecal } \\
\text { calcium } \\
\text { (mg) }\end{array}$ & $\begin{array}{l}\text { Total } \\
\text { calcium } \\
\text { excreted } \\
\text { (mg) }\end{array}$ & $\begin{array}{c}\text { Calcium } \\
\text { balance } \\
\text { (mg) }\end{array}$ \\
\hline Rice & 3215 & $529 \cdot I$ & $142 \cdot I$ & $339 \cdot 8$ & $48 r \cdot 9$ & $47 \cdot 2$ \\
\hline Rice-tapioca & 3337 & $586 \cdot 0$ & 113.2 & 319.5 & $432 \cdot 7$ & 153.3 \\
\hline Difference & - & $5^{6 \cdot 9}$ & $-28 \cdot 9 \pm 33 \cdot 3$ & $-20 \cdot 3 \pm 31 \cdot 3$ & $-49 \cdot 2$ & $106 \cdot I^{*} \pm 35.9$ \\
\hline
\end{tabular}

Table 5. Average daily intake, excretion and balance of phosphorus of subjects on rice and rice-tapioca diets

\begin{tabular}{|c|c|c|c|c|c|c|}
\hline Diet & $\begin{array}{c}\text { Calorie } \\
\text { intake } \\
\text { (Cal.) }\end{array}$ & $\begin{array}{l}\text { Phosphorus } \\
\text { intake } \\
\text { (mg) }\end{array}$ & $\begin{array}{l}\text { Urinary } \\
\text { phosphorus } \\
\text { (mg) }\end{array}$ & $\begin{array}{c}\text { Faecal } \\
\text { phosphorus } \\
(\mathrm{mg})\end{array}$ & $\begin{array}{c}\text { Total } \\
\text { phosphorus } \\
\text { excreted } \\
\text { (mg) }\end{array}$ & $\begin{array}{l}\text { Phosphorus } \\
\text { balance } \\
\text { (mg) }\end{array}$ \\
\hline $\begin{array}{l}\text { Rice } \\
\text { Rice-tapioca }\end{array}$ & $\begin{array}{l}3215 \\
3337\end{array}$ & $\begin{array}{l}1153^{\circ} 8 \\
1178 \cdot 0\end{array}$ & $\begin{array}{l}298 \cdot 4 \\
238 \cdot 1\end{array}$ & $\begin{array}{l}659 \cdot 6 \\
470 \cdot 3\end{array}$ & $\begin{array}{l}957 \cdot 9 \\
708 \cdot 4\end{array}$ & $\begin{array}{l}195 \cdot 9 \\
469 \cdot 6\end{array}$ \\
\hline Difference & - & $24 \cdot 2$ & $-60 \cdot 3 \pm 25 \cdot 7$ & $-189 \cdot 3 \pm 87 \cdot 8$ & -249.5 & $273 \cdot 7^{*} \pm 96 \cdot 5$ \\
\hline
\end{tabular}

with $0.2-0.4 \%$ calcium (mostly as calcium sulphate) associated as an impurity. As the amount of salt taken with the experimental diets was about $35 \mathrm{~g} /$ day, the calcium contributed by the salt to the diets was $108 \mathrm{mg} /$ day. If high-grade salt such as is being used in Europe and America had been used in the diets, the total calcium content 


\section{I4 H. B. N. Murthy, M. Swaminathan and V. Subrahmanyan 1954}

of the diet would have been lowered by $108 \mathrm{mg} /$ day, whereas through fortuitous inclusion of calcium in the bazaar salt the intake of calcium was considerably increased. The significance of this will be discussed in a later communication.

Nitrogen metabolism. The average daily nitrogen intake on the rice diet and on the rice-tapioca diet was 9.69 and $8.93 \mathrm{~g}$ respectively. The average loss of nitrogen in the faeces was nearly of the same order on both the diets, showing thereby that the digestibility of the food protein was not affected to any appreciable extent by the incorporation of tapioca flour. The loss of nitrogen in the urine was appreciably less on the rice-tapioca diet than on the rice diet. All the subjects were in positive nitrogen equilibrium. The average quantity of nitrogen retained daily by the subjects was nearly the same on both the diets $(2.65$ and $2.75 \mathrm{~g})$, the difference being not statistically significant.

Calcium metabolism. Four subjects were in positive calcium balance and two subjects were in negative balance on the rice diet. All six subjects were in positive calcium balance on the rice-tapioca diet. Though the average daily intake of calcium on the rice-tapioca diet was $57 \mathrm{mg}$ more than that on the rice diet, the loss of calcium in urine and faeces was $49 \mathrm{mg}$ less. The average retention of calcium was $47 \mathrm{mg}$ on the rice diet as compared with $153 \mathrm{mg}$ on the rice-tapioca diet. The results on statistical examination showed a significant difference in the balance in favour of the rice-tapioca diet.

Phosphorus metabolism. The average intake of phosphorus was nearly the same on both diets ( 1155 and 1 I $78 \mathrm{mg}$ ). The average absorption of phosphorus on the rice diet was $43 \%$ as compared with $60 \%$ on the rice-tapioca diet. The loss of phosphorus in the urine was appreciably less on the rice-tapioca diet. The average retention of phosphorus on the rice-tapioca diet was apparently greater than that observed on the rice diet, the difference being statistically significant.

\section{DISCUSSION}

It is evident from the results that about $25 \%$ of the rice in a vegetarian diet, as used in the present experiment, could be replaced by an equal quantity of tapioca flour without lowering the retention of nitrogen, calcium and phosphorus. In fact, an increase in the retention of calcium and phosphorus was observed as a result of such replacement. On the rice-tapioca diet the subjects ate $19 \mathrm{oz}$. rice and $5.25 \mathrm{oz}$. tapioca daily. These two foodstuffs supplied about $80 \%$ of the calories in the diet. The average daily calorie intake of the subjects was about 3200 Cal. Since the subjects were doing moderate to active physical work for about $8 \mathrm{~h}$ a day in the laboratory, the calorie intake cannot be considered as being in excess of their requirements (Aykroyd, Patwardhan \& Ranganathan, 1951).

Basu \& Basak (1939) reported that the average minimum protein requirements of adult human beings (of $70 \mathrm{~kg}$ body-weight) on a poor rice diet were $46.4 \mathrm{~g}$ when the calorie intake was $3000 \mathrm{Cal}$. On this basis the average minimum protein requirements of the subjects (average body-weight $49 \mathrm{~kg}$ ) in the present experiment were about $33 \mathrm{~g}$ (equal to $5.3 \mathrm{~g} \mathrm{~N}$ ) per day. The actual protein intake on the rice diet and on the ricetapioca diet was 60 and $5^{6} \mathrm{~g}$ respectively. The average daily retention of nitrogen in 
the experimental subjects was nearly of the same order on both the diets. The high nitrogen retentions observed in the present experiment may be partly due to the fact that, in the calculation of nitrogen balance, no allowance was made for the loss of nitrogen through sensible and insensible perspiration. The high nitrogen retentions observed in the present experiment are similar to those reported by Patwardhan, Mukundan, Rama Sastri \& Tulpule (1949) on diets based mainly on vegetable proteins. The results show that the rice-tapioca diet of the composition used in the present experiment supplies more than the minimum quantity of protein required for maintaining nitrogen balance in adult human beings.

The calcium requirements of adult human beings have been estimated as $10 \mathrm{mg} / \mathrm{kg}$ body-weight (Steggerda \& Mitchell, 1946; Leitch, 1936-7; Holmes, 1944-5). The average calcium requirements of the subjects of the present investigation were about $500 \mathrm{mg} /$ day according to the above estimate. The average intake of calcium by the experimental subjects on the rice diet and on the rice-tapioca diet was 529 and $586 \mathrm{mg}$ respectively. The average retention of calcium on the rice-tapioca diet was significantly more than that observed on the rice diet. In similar studies on diets based on rice and wheat, Basu, Basak \& Rai Sircar (1939) found the average calcium requirement for adult human beings to be $0.388 \mathrm{~g} / 70 \mathrm{~kg}$ body-weight.

Basu et al. (1939) reported that the average phosphorus requirement of adult human beings fed on diets based on rice and wheat was $\mathrm{I} \cdot 0 \mathrm{~g} / 70 \mathrm{~kg}$ body-weight. According to these findings, the average phosphorus requirement of the subjects in the present investigation was about $0.7 \mathrm{~g}$. The actual intake of phosphorus on the rice and rice-tapioca diets was $\mathrm{I} \cdot 15$ and $\mathrm{I} \cdot 17 \mathrm{~g}$. respectively. Even though the average intake of phosphorus was nearly the same on both the diets, the average absorption of phosphorus on the rice-tapioca diet $(60 \%)$ was greater than that $(43 \%)$ observed on the rice diet. This is probably due to the fact that tapioca contains very little phytate phosphorus, whereas $50 \%$ of the total phosphorus in raw milled rice is present as phytate (Sundararajan, 1938). This observation is in conformity with the findings of Walker, Fox \& Irving (1948) who reported that on the same level of intake the retention of phosphorus was greater when the phytate phosphorus content of the diet was reduced.

\section{SUMMARY}

I. The metabolism of nitrogen, calcium and phosphorus was studied in six men fed on diets based on rice and on a mixture of $75 \%$ rice and $25 \%$ tapioca. The composition of the rice diet was similar to that ordinarily consumed by people belonging to the low-income groups in many parts of India.

2. The average daily intake of nitrogen on the rice diet and the rice-tapioca diet was 9.69 and $8.93 \mathrm{~g}$ respectively. In spite of a slightly lower nitrogen intake on the rice-tapioca diet, the average retention of nitrogen on the two diets was $2 \cdot 65$ and $2 \cdot 75 \mathrm{~g}$ respectively.

3. Four of the six experimental subjects were in positive calcium balance and two in negative balance on the rice diet. All the six subjects were in positive calcium balance on the rice-tapioca diet. The average daily retention of calcium was $47^{\cdot 2} \mathrm{mg}$ 


\section{i6 H. B. N. Murthy, M. Swaminathan and V. Subrahmanyan I954}

on the rice diet and $153.4 \mathrm{mg}$ on the rice-tapioca diet, the difference being statistically significant.

4. The average daily intake of phosphorus was nearly of the same order on both the diets. The average absorption of phosphorus was only $43 \%$ on the rice diet as compared with $60 \%$ on the rice-tapioca diet. The daily average retention of phosphorus was $196 \mathrm{mg}$ on the rice diet and $470 \mathrm{mg}$ on the rice-tapioca diet, the difference in the retention being statistically significant.

We are much indebted to Mr A. N. Sankaran for the statistical analysis of the results.

\section{REFERENCES}

Aykroyd, W. R., Patwardhan, V. N. \& Ranganathan, S. (195 I). Hlth Bull., Simla, no. 23, p. I5.

Basu, K. P. \& Basak, M. N. (1939). Indian F. med. Res. 27, I 5 .

Basu, K. P., Basak, M. N. \& Rai Sircar, B. C. (1939). Indian $\mathcal{F}$. med. Res. 27, 471.

Fiske, C. H. \& Subbarow, Y. (1925). F. biol. Chem. 66, 375.

Holmes, J. O. (1944-5). Nutr. Abstr. Rev. 14, 587.

Leitch, I. (1936-7). Nutr. Abstr. Rev, 6, 553.

McCrudden, F. H. (I91 I-12). F. biol. Chem. 10, 187.

Patwardhan, V. N., Mukundan, R., Rama Sastri, B. V. \& Tulpule, P. G. (1949). Indian ₹. med. Res. $37,327$.

Steggerda, F. R. \& Mitchell, H. H. (r946). F. Nutr. 3r, 407.

Subrahmanyan, V., Murthy, H. B. N. \& Swaminathan, M. (1954). Brit. F. Nutr. 8, I.

Sundararajan, A. R. (1938). Indian F. med. Res. $25,685$.

Walker, A. R. P., Fox, F. W. \& Irving, J. T. (1948). Biochem. F. 42, 452. 